Andrzej Topij

Uniwersytet Kazimierza Wielkiego w Bydgoszczy

\title{
Niemiecko-estoński i niemiecko-łotewski układ o przesiedleniu Niemców bałtyckich (1939 rok)
}

Zarys treści: Artykuł porusza kwestię przesiedlenia mniejszości niemieckiej z Łotwy i Estonii do III Rzeszy jesienią 1939 r. i skupia się na genezie niespodziewanej akcji przesiedleńczej oraz przedstawia rokowania niemiecko-estońskie i niemiecko-łotewskie, które doprowadziły do podpisania odpowiednich układów.

Outline of content: The article deals with the question of resettlement of the German minority from Latvia and Estonia to the Third Reich in the autumn of 1939, focusing on the genesis of an unexpected resettlement action, and presenting the German-Estonian and German-Latvian negotiations that ended with the signing of treaties.

Słowa kluczowe: Łotwa, Estonia, Niemcy bałtyccy, III Rzesza, układ o przesiedleniu 1939 r.

Keywords: Latvia, Estonia, Baltic Germans, Third Reich, treaty on the resettlement of 1939

Przesiedlenie mniejszości niemieckiej z Łotwy i Estonii w 1939 r. III Rzesza oficjalnie wiązała z tzw. mową pokojową Adolfa Hitlera, którą kanclerz wygłosił w Reichstagu 6 października tego roku. Stwierdził w niej m.in.:

całą wschodnią i południowo-wschodnią Europę częściowo wypełniają odpryski niemieckiego narodu. Właśnie w tym leży powód i przyczyna następujących międzypaństwowych konfliktów. W epoce pryncypium narodowości i idei rasowej utopijna jest wiara, iż członkowie wysokowartościowego narodu mogą zostać zasymilowani. Zatem zadaniem perspektywicznego porządku europejskiego życia jest przeprowadzenie przesiedleń, aby tym sposobem zlikwidować część europejskiego podłoża konfliktów ${ }^{1}$.

Myśl tę rozwinął minister spraw zagranicznych Joachim von Ribbentrop w swoim wystąpieniu w Gdańsku 24 października 1939 r. Podkreślił w nim, iż

${ }^{1}$ Der großdeutsche Freiheitskampf. Reden Adolf Hitlers, t. 1, München 1943, s. 323. 
jego kraj chce przesiedlić wszystkich Niemców z Europy Centralnej, Wschodniej i Południowo-Wschodniej, aby stworzyć jasne, stabilne granice i uniknąć możliwości przyszłego konfliktu. „Granice Rzeszy na północy, wschodzie, południu i zachodzie są teraz ostateczne" - stwierdził². Planowane przesiedlenia dotyczyć miały Niemców żyjących w południowym Tyrolu, we Włoszech, Danii, na terenach Rzeczypospolitej zagarniętych przez Związek Radziecki, Litwy, Łotwy, Estonii, Rumunii i Bułgarii.

W przypadku krajów bałtyckich sytuacja była bardziej złożona. W rzeczywistości przedstawione argumenty były tylko pozorami. Rządowi Rzeszy chodziło o zabranie Niemców z obszarów znajdujących się w radzieckiej strefie wpływów i zasiedlenie nimi ziem polskich włączonych do Niemiec, tzw. wcielonych ziem wschodnich (Eingegliederte Ostgebiete), co nastąpiło 8 października 1939 r. Dzień wcześniej powołany został do życia na mocy tzw. dekretu o umocnieniu niemczyzny Urząd Komisarza Rzeszy ds. Umocnienia Niemczyzny z Reichsführerem SS Heinrichem Himmlerem na czele. W punkcie pierwszym dekretu władze III Rzeszy stawiały sobie za cel „sprowadzenie do Rzeszy tych Reichs- i Volksdeutschów mieszkających za granicą, których przewidziano do ostatecznego powrotu do kraju". $\mathrm{W}$ drugim punkcie w zakamuflowanej formie zapowiedziano wysiedlenia rdzennej ludności zamieszkałej na danym terenie jako „zlikwidowanie szkodliwego wpływu takich narodowo obcych grup, które stanowią niebezpieczeństwo dla Rzeszy i niemieckiej wspólnoty". Dekret wskazywał ustawę o uzyskaniu ziemi na rzecz Wehrmachtu z 29 marca 1935 r., która miał pomóc w pozyskiwaniu terenów potrzebnych dla repatriantów. Naturalnie wiązało się to $\mathrm{z}$ wysiedleniem ludności mieszkającej do tej pory na tych obszarach ${ }^{3}$.

Podpisanie niemiecko-radzieckiego układu o nieagresji 23 sierpnia 1939 r. wywołało poważne zaniepokojenie wśród przywódców mniejszości niemieckiej na Łotwie i w Estonii, tym bardziej, że w wkrótce w ślad za tym poszły żądania ZSRR wobec Estonii, a potem Łotwy i Litwy odnośnie do rozmieszczenia oddziałów Armii Czerwonej w bazach na terenie tych krajów i podpisania układów o przyjaźni, pomocy i współpracy wzajemnej ${ }^{4}$. Po wybuchu II wojny światowej niektórzy z nich udali się do Rzeszy, aby zabiegać o objęcie Niemców bałtyckich ochroną prawną ze strony Niemiec. Szczególnie intensywne kroki w tym kierunku podjął Erhard Kroeger, będący kierownikiem krajowym (Landesleiter) ruchu narodowo-socjalistycznego na Łotwie. Przez prawie cały wrzesień bawił on w Sopocie, gdzie starał się przekonać Himmlera o niebezpieczeństwie grożącym Niemcom w przypadku wkroczenia Armii Czerwonej do krajów bałtyckich. Początkowo Reichsführer SS starał się bagatelizować sprawę, twierdząc np., że „może bolszewicy teraz to już

\footnotetext{
2 Dokumente der Deutschen Politik, t. 7, cz. 1, hrsg. P. von Meier-Benneckenstein, Berlin 1940, s. 375.

${ }^{3}$ Wybór tekstów źródłowych $z$ historii państwa i prawa. Okres okupacji hitlerowskiej na ziemiach polskich, wyb. i oprac. A. Konieczny, Wrocław 1980, s. 16-18.

${ }^{4}$ O okolicznościach podpisania tych układów, patrz: T.U. Raun, Estonia nad the Estonians, Stanford 2001, s. 140-141; A. Plakans, Th Latvians, A Short History, Stanford 1995, s. 108.
} 
nie ci sami bolszewicy co w 1919 r." ${ }^{5}$ (w trakcie kilkumiesięcznej okupacji Łotwy wymordowali wówczas także kilkudziesięciu Niemców bałtyckich). Później jednak zmienił zdanie i zaczął nakłaniać Hitlera, aby przesiedlić ludność niemiecką z Łotwy i Estonii do Rzeszy. Być może wpływ na to miała wizyta Kroegera u szefa Głównego Urzędu Bezpieczeństwa Rzeszy Reinharda Heydricha w dniu 27 września. Heydrich poinformował przedstawiciela Niemców łotewskich, że według danych wywiadu należy oczekiwać wkroczenia Armii Czerwonej w najbliższych godzinach nie tylko do Estonii, ale i na Łotwę. Wówczas Werner Best (oficer SS, wówczas zastępca Heydricha w SD), obecny przy rozmowie, zaproponował, aby Niemcom bałtyckim przyznać obywatelstwo niemieckie i tym samym zapewnić im bezpieczeństwo ${ }^{6}$.

Urząd Spraw Zagranicznych dowiedział się o zamiarze sprowadzenia Niemców z Łotwy i Estonii 28 września 1939 r. Wówczas to Heydrich poinformował sekretarza stanu Ernsta von Weizsäckera o podjęciu decyzji w tej sprawie przez Hitlera. Kwestia ta miała być uzgodniona w trakcie odbywających się właśnie pertraktacji Ribbentropa z Wiaczesławem Michajłowiczem Mołotowem w sprawie wypracowania traktatu o granicy i przyjaźni ${ }^{7}$. Reichsführer SS postulował, przez Hermanna Behrendsa, szefa Głównego Urzędu Placówki ds. Niemców Etnicznych (Hauptamt Volksdeutsche Mittelstelle), aby kwestię przesiedlenia Niemców etnicznych z Estonii potraktować następująco: w razie spokojnego, jak to ujął, rozwoju wypadków wynegocjować i podpisać umowę o przesiedleniu, zabezpieczającą wyraźnie prawa majątkowe, zaś w razie wybuchu anarchii w Estonii, na wypadek wkroczenia tam wojsk radzieckich, natychmiast ogłosić volksdeutschów reichsdeutschami i wziąć ich pod niemiecką ochronę razem $\mathrm{z}$ ich majątkiem oraz natychmiast ewakuować statkami transportowymi konwojowanymi przez okręty wojenne ${ }^{8}$. Weizsäcker natychmiast zadzwonił do Ribbentropa, informując go, iż należałoby wynegocjować z ZSRR umowę o traktowaniu mniejszości niemieckiej w razie wkroczenia wojsk radzieckich do Estonii, z zabezpieczeniem jej praw majątkowych, a najlepszym rozwiązaniem byłoby podpisanie trójstronnego porozumienia, przewidującego raczej szybkie przesiedlenie tamtejszych Niemców na statkach Rzeszy. Jednocześnie Weizsäcker zaznaczał, iż trudno jest przewidzieć podpisanie podobnej umowy z Łotwą ${ }^{9}$. Estonia nie została tu wyróżniona przypadkowo. Kilka dni wcześniej, 23 września 1939 r. ZSRR wysunął bowiem względem niej pierwsze żądania ${ }^{10}$.

Radziecko-niemiecki układ o granicy i przyjaźni, podpisany 28 września 1939 r., w jednym z tajnych protokołów przewidywał przesiedlenie ludności

${ }^{5}$ E. Kroeger, Der Auszug aus der alten Heimat. Die Umsiedlung der Baltendeutschen, Tübingen 1967, s. 93.

${ }^{6}$ P. Łossowski, Przesiedlenie Niemców $z$ państw bałtyckich w latach 1939-1941, „Dzieje Najnowsze” 36, 2004, nr 1, s. 76.

7 Akten zur deutschen auswärtigen Politik 1918-1945 (dalej: ADAP), Seria D, t. 7, Baden-Baden 1953, s. 125.

8 Ibidem, s. 126.

9 Ibidem, s. 127.

10 J. Korzeń, Dramat narodów bałtyckich, Warszawa 1987, s. 33. 
niemieckiej z terenów zajętych przez ZSRR ${ }^{11}$. Natomiast Estonia, a wkrótce potem Łotwa i, jako ostatnia, Litwa, podpisały ze Związkiem Radzieckim układy o wzajemnej pomocy ${ }^{12}$. W szczególności wiadomość o zawarciu układu estońsko-radzieckiego wywołała w pierwszych dniach prawdziwą panikę, głównie wśród Niemców żyjących blisko radzieckiej granicy, np. w Narwie czy Haapsalu ${ }^{13}$. W związku z tym poselstwo niemieckie $\mathrm{w}$ Tallinie poufnie poinformowało kierownictwo mniejszości niemieckiej, że w razie rzeczywistego niebezpieczeństwa Rzesza przejmie na siebie reprezentowanie jej interesów ${ }^{14}$. Weizsäcker 5 października 1939 r. wysłał pilny telegram do posła niemieckiego w Tallinie, Hansa Frohweina, w którym polecił mu poinformowanie rządu estońskiego, iż Rzesza Niemiecka, zważywszy rozwój sytuacji, jest zmuszona wziąć pod swoją ochronę tutejszych volksdeutschów. Poseł miał też wyrazić oczekiwanie swojego rządu, iż władze estońskie podejmą konieczne kroki celem zabezpieczenia życia i własności wszystkich Niemców oraz że bez żadnej zwłoki pozwolą wszystkim Niemcom, którzy wyrażą taką chęć, opuścić Estonię ${ }^{15}$. Weizsäcker poprosił Naczelne Dowództwo Marynarki Wojennej (Oberkommando Kriegsmarine), żeby wydzieliło określone jednostki i postawiło je w stan gotowości, aby, w razie potrzeby, umożliwić natychmiastowe wypłynięcie do Rygi, Libawy, Windawy, Pernawy i Tallina ${ }^{16}$. Jak widzimy, przygotowania te miały miejsce jeszcze przed wystąpieniem Hitlera w Reichstagu i złożeniem oficjalnie jego oferty. Inna sprawa, że w Urzędzie Spraw Zagranicznych szybko się przestraszono możliwych konsekwencji takiej repatriacji, wychodząc nie bez racji z założenia, iż pospieszna akcja wywoła poważne niepokoje i ogólną panikę. W związku z tym już następnego dnia postanowiono ją, czasowo, wstrzymać ${ }^{17}$.

Inna sprawa, że nie tylko ci Baltendeutsche zareagowali tak panicznie. Także cztery tysiące Rosjan (zapewne białogwardyjskich emigrantów) żyjących w Finlandii wystąpiło $z$ inicjatywą natychmiastowego opuszczenia tego kraju i wyjazdu do Rzeszy. Z kolei przedstawiciele mniejszości szwedzkiej w tym kraju zaczęli mówić o wyjeździe do Szwecji ${ }^{18}$. A przecież było to na początku października, kiedy to Związek Radziecki nie wysuwał jeszcze żadnych roszczeń wobec Finlandii.

W wytycznych dla poselstw w Tallinie i Rydze z 6 października 1939 r., a więc zaraz po wygłoszeniu przez Hitlera wspomnianej wyżej mowy w Reichstagu, Weizsäcker podkreślał, iż oficjalnie akcji przesiedleńczej z Łotwy i Estonii nie należy

11 T.U. Raun, op. cit., s. 143.

12 J. Korzeń, op. cit., s. 33.

${ }^{13}$ H. Bernsdorff, Gesundheitsdienst und Fürsorge während der deutsch-baltischer Umsiedlung, „Baltische Hefte" 16, 1970, s. 211.

${ }^{14}$ D. Loeber, Diktierte Option. Die Umsiedlung der Deutschbalten aus Estland und Lettland 19391941. Dokumentation, Neumünster 1972, dok. 47, s. 50-51.

15 ADAP, Seria D, t. 7, s. 170.

16 D. Loeber, op. cit., dok. 56, s. 58-59.

17 Ibidem, dok. 64, s. 68.

18 Politisches Archiv des Auswärtigen Amtes (dalej: PAAA), Berlin, R 29895 - Büro des Staatssekretärs, Zwischenfall Litauen-Sowjetunion-Estland-Lettland, Helsinki, den 11. Oktober 1939, s. 216. 
w ogóle wiązać z traktatami podpisanymi przez te kraje z ZSRR, lecz uzasadniać życzeniem Rzeszy zapewnienia cennych niemieckich sił dla samych Niemiec ${ }^{19}$.

Niezależnie od takiej interpretacji zapowiadanej akcji, strona radziecka wyrażała początkowo niezadowolenie z podjętej przez Rzeszę decyzji. Dał temu wyraz m.in. zastępca ludowego komisarza spraw zagranicznych, Władimir Pietrowicz Potemkin w rozmowie $\mathrm{z}$ ambasadorem Friedrichem-Wernerem von der Schulenburgiem w dniu 11 października. Potemkin prosił swojego rozmówcę, aby ten natychmiast przekazał negatywną ocenę Stalina i Mołotowa, zdumionych panicznym wyjazdem Niemców z Łotwy i Estonii, mimo braku podstaw do twierdzenia, że grozi im jakiekolwiek niebezpieczeństwo. Natomiast „ucieczka” Niemców musiała w jego ujęciu - bardzo kompromitować akcję Związku Radzieckiego ${ }^{20}$. Zarzut ten odrzucił naturalnie w swojej odpowiedzi z 13 października Ribbentrop, twierdząc, iż łączenie akcji radzieckiej i niemieckiej jest wyłącznie zabiegiem angielskiej propagandy, chcącej zakłócić nowe, dobrosąsiedzkie relacje między Berlinem a Moskwą, a o panicznej ucieczce Niemców nie może być najmniejszej mowy. Minister Rzeszy podkreślił przy tym, że przeprowadzana akcja przebiega planowo, w spokoju i prawdopodobnie przeciągnie się na wiele miesięcy. Przyczyną zaś jej podjęcia nie jest obawa, iż Niemcom zagraża jakiekolwiek niebezpieczeństwo ze strony ZSRR, ale konieczność przejęcia opuszczonych gospodarstw, placówek handlowych i zakładów rzemieślniczych na ziemiach polskich wcielonych do III Rzeszy. Tak więc przesiedlenie Niemców z krajów bałtyckich, i to w okresie zimowym, wynika wyłącznie z zamiaru przywrócenia tamtejszego życia gospodarczego ${ }^{21}$. Zdaniem Ribbentropa, przesiedlenie Niemców wykluczało ewentualne zakłócenia w relacjach między III Rzeszą a krajami bałtyckimi i pośrednio ZSRR. Jak donosił w swoim raporcie z 14 października 1939 r. Schulenburg, pismo Ribbentropa w pewnym stopniu uspokoiło Mołotowa ${ }^{22}$.

Zanim rządy łotewski i estoński zostały oficjalnie poinformowane o całej sprawie, rankiem 7 października 1939 r. wypłynęły z Gdańska statki transportowe do Rygi i Tallina. Na pytanie łotewskiego ministra spraw zagranicznych Vilhelmsa Muntersa, co to oznacza, poseł III Rzeszy w Rydze nie był w stanie udzielić żadnej odpowiedzi. Hans Kotze zwrócił się więc wieczorem do przywódcy ruchu narodowosocjalistycznego na Łotwie, Kroegera, który właśnie wrócił z Rzeszy, z prośbą o bliższe informacje. Dopiero potem był w stanie udzielić łotewskiemu ministrowi wyjaśnień o powziętym przez rząd Rzeszy planie przesiedlenia volksdeutschów z kilku krajów, w tym Łotwy, podkreślając jednocześnie, iż cała akcja nie ma absolutnie jakiegokolwiek związku z zawartymi przez kraje bałtyckie układami ze Związkiem Radzieckim. Dodał jednocześnie, iż uczyni co tylko w jego mocy, aby

\footnotetext{
19 ADAP, Seria D, t. 7, s. 181.

20 Ibidem, s. 208.

21 Ibidem, s. 221.

22 Ibidem, s. 222.
} 
uniknąć dalszego niepokojenia łotewskiej opinii publicznej i przeprowadzić akcję przesiedleńczą planowo, $\mathrm{w}$ spokoju, $\mathrm{z}$ uwzględnieniem likwidacji praw majątkowych w zgodzie z władzami łotewskimi. Munters natychmiast wyraził życzenie swojego rządu zawarcia odpowiedniego układu w tej sprawie. Wskazał przy tym jasno, że „rząd łotewski w żadnym wypadku nie dopuści, aby tysiące volksdeutschów z małymi, naprędce spakowanymi bagażami zgromadziło się przed poselstwem lub $\mathrm{w}$ porcie ryskim $\mathrm{w}$ oczekiwaniu na transport"23. Łotewski minister spraw zagranicznych dobitnie podkreślił, że jego rząd nie będzie stawiał żadnych przeszkód na drodze tym, którzy zechcą opuścić Łotwę, ale „wszystkimi dostępnymi środkami będzie się sprzeciwiał transportowi w innej formie niż przewiduje prawo" ${ }^{24}$. Jeszcze tego samego wieczora łotewska agencja telegraficzna podała, że poseł niemiecki poprosił łotewski rząd o wydanie zgody na przesiedlenie mniejszości niemieckiej. Repatriacja uzasadniona była, naturalnie, wyłącznie ideą wyrażoną przez Hitlera w jego wystąpieniu w Reichstagu 6 października ${ }^{25}$.

Akcja przesiedlenia Niemców bałtyckich była równie nieoczekiwana dla rządu estońskiego. Oficjalne oświadczenie w tej sprawie wydano nieco później, bo 9 października. Władze wyraźnie w nim podkreśliły swoje pragnienie natychmiastowego rozpoczęcia pertraktacji w sprawie zawarcia odpowiedniego układu z III Rzeszą ${ }^{26}$.

Początkowo poseł niemiecki w Rydze stał na stanowisku, że podpisanie układu międzypaństwowego nie jest ani potrzebne, ani możliwe. W jego opinii wystarczyło wezwać Niemców do wyjazdu do III Rzeszy, a po szybkim wydaniu paszportów wysłać ich drogą morską do nowej ojczyzny. Rychło strona niemiecka musiała jednak zmienić zdanie ${ }^{27}$. Stanowisko rządów obu krajów bałtyckich spowodowało, że wbrew zamiarowi Berlina nie można było rozpocząć natychmiastowego przesiedlenia, lecz najpierw stworzyć podstawę prawną. Pertraktacje rozpoczęły się wszakże prawie że natychmiast, w Tallinie 9 października, a w Rydze dzień później. Ze strony niemieckiej zadanie to spoczywało w rękach odpowiednich posłów. Do Rygi i Tallina przybyli też przedstawicie Urzędu Spraw Zagranicznych na czele z Fritzem von Twardowskim, zastępcą dyrektora VI Departamentu (ds. kultury), i samym Wernerem Lorenzem, stojącym na czele Placówki ds. Niemców Etnicznych (Volksdeutsche Mittelstelle) ${ }^{28}$. Estońskim partnerem był były minister spraw zagranicznych i poseł na Węgrzech Johannes Markus, a łotewskim minister sprawiedliwości Hermanis Apsītis, aczkolwiek często towarzyszył mu minister spraw zagranicznych Munters. Ponadto Kārlis Ulmanis, prezydent i premier Łotwy w jednej osobie, osobiście włączał się w pertraktacje, interesując się przy tym wszelkimi

23 D. Loeber, op. cit., dok. 89, s. 100-102.

${ }^{24}$ PAAA, Gesandtschaft Riga 91, 84/4, Bericht, 7.10.1939, s. 558.

25 D. Loeber, op. cit., dok. 74, s. 82-83.

${ }^{26}$ Ibidem, dok. 73, s. 81-82.

27 P. Łossowski, op. cit., s. 81 .

28 D. Loeber, op. cit., dok. 73, s. 107; PAAA - Gesandschafts Riga 91, 84/4, Bericht, den 6. Oktober 1939, s. 363. 
szczegółami ${ }^{29}$. Tym samym jasno było widać, że strona łotewska przywiązywała do nich o wiele większą wagę niż estońska. Nie powinno też dziwić, iż pertraktacje z Łotwą trwać miały aż trzy razy dłużej.

Minister Rzeszy w osobistym piśmie z 9 października polecił posłom prowadzenie pertraktacji w jak najszybszym tempie i dopilnowanie, aby układy weszły $\mathrm{w}$ życie $\mathrm{w}$ momencie ich podpisania. Wyjaśniał przy tym, że w kwestii przynależności do niemieckiej grupy narodowej powinni być możliwie jak najbardziej elastyczni ${ }^{30}$. Jednocześnie Urząd Spraw Zagranicznych przesłał posłom, w celu ułatwienia pertraktacji, projekt traktatu, który wszakże zawierał tylko propozycje odnośnie do przeprowadzenia opcji, zaś regulację wszystkich spraw majątkowych rezerwował dla późniejszych rozmów. Przewidywał m.in. prawo podjęcia decyzji o wyjeździe przez obywateli łotewskich i estońskich do 31 marca $1940 \mathrm{r}$. W przypadku złożenia wniosku o przyjęcie obywatelstwa niemieckiego jego zasadność miała być zbadana przez dane niemieckie poselstwo ${ }^{31}$. Na to nie były gotowe rządy estoński, a zwłaszcza łotewski. Zarówno Ryga, jak i Tallin życzyły sobie możliwie szczegółowego uregulowania tych kwestii, co było skądinąd całkiem zrozumiałe, zważywszy, iż oba rządy chciały uniknąć spłacenia Niemcom pozostawionego majątku przesiedleńców, gdyż to byłoby nie do udźwignięcia dla ich własnych gospodarek. Dla strony niemieckiej było całkowicie jasne, że ten problem ma ogromne znaczenie dla gospodarki i finansów Łotwy i Estonii. Berlin zdawał sobie zapewne sprawę, że pełne odszkodowanie, według wartości rynkowej, za pozostawione przez przesiedleńców mienie doprowadzi oba kraje do potężnego zadłużenia zagranicznego ${ }^{32}$.

Co się tyczy samych pertraktacji, udział w nich Niemców bałtyckich był możliwy tylko w ograniczonym zakresie, i to raczej pośrednio. Większe możliwości mieli w Estonii niż na Łotwie. W Tallinie kilka czołowych postaci z tego środowiska nie tylko zostało włączonych do delegacji niemieckiej jako doradcy, lecz także brało udział w pracach komitetów. Należeli do nich: Erich von Bremen, W. Heldt, Marthin Luther, B. Meyer-Landrut, Arvid von Nottbeck, A. Riesenkampf, O. von Schulmann, Helmuth Weiss, Wilhelm Baron Wrangell. Jak twierdził jeden z nich, von Nottbeck, przyszły minister sprawiedliwości w Dolnej Saksonii, dążyli przede wszystkim do tego, aby jak najszybciej zawrzeć traktat, nawet kosztem praw majątkowych mniejszości niemieckiej ${ }^{33}$.

$\mathrm{Na}$ Łotwie poselstwo niemieckie, biorąc pod uwagę złe stosunki między tamtejszą mniejszością niemiecką a rządem, zrezygnowało ze współpracy z jej przedstawicielami, aby nie utrudniać pertraktacji. Tylko w pojedynczych przypadkach

29 J. von Hehn, Die Umsiedlung der baltischen Deutschen. Das letzte Kapitel baltischdeutscher Geschichte, Marburg 1982, s. 107-108.

${ }^{30}$ D. Loeber, op. cit., dok. 94, s. 108.

${ }^{31}$ Ibidem, dok. 95, s. 108-110.

32 Ibidem.

33 J. von Hehn, Die Umsiedlung..., s. 109. 
przedstawiciele lokalnych Niemców, wyłącznie prawnicy, zostali włączeni w skład podkomitetów ${ }^{34}$.

Niemcy zaproponowali delegacji estońskiej wykup całego majątku pozostawianego przez wyjeżdżających (oczywiście pieniądze trafiłyby wtedy do skarbu Rzeszy, optanci otrzymaliby „odszkodowanie” na polskich ziemiach okupowanych). Strona estońska stanowczo odrzuciła takie rozwiązanie, więc zawarcie porozumienia clearingowego przesunięto na późniejszy termin ${ }^{35}$. Teraz pertraktacje niemiecko-estońskie posuwały się szybko i doprowadziły do pomyślnego rezultatu już po upływie niecałego tygodnia. $W$ ich trakcie poseł niemiecki Frohwein wyszedł poza wzór przesłanego mu z Berlina protokołu i uzyskał korzystne rozwiązania w sprawie majątku niemieckich stowarzyszeń, szkół, kościołów i placówek kulturalnych ${ }^{36}$. Chcąc uniknąć oczekiwania na ratyfikację dokumentu, zdecydowano się na formę protokołu, co umożliwiło wejście układu w życie bez ratyfikacji parlamentu, jak było przyjęte w przypadku traktatów międzypaństwowych. Protokół został jedynie podpisany przez prezydenta Konstantina Pätsa następnego dnia, tj. 16 października 1939 r. Był dokumentem stosunkowo zwięzłym; liczył pięć artykułów. Przede wszystkim określał uprawnionych do wzięcia udziału w akcji przesiedleńczej. Były to osoby, których nazwiska znajdowały się w katastrze Niemieckiej Administracji Kulturalnej (Deutsche Kulturverwaltung) lub dostarczyły zaświadczenie estońskiego Ministerstwa Spraw Wewnętrznych o niemieckiej przynależności narodowej. Razem z nimi mogli wyjechać członkowie ich rodzin: małżonkowie, dzieci, rodzice, nawet gdy zgodnie z prawem estońskim byli zaliczeni do innej narodowości, w tym estońskiej (np. estońska ustawa o narodowości z 1934 r. zaliczała dzieci z małżeństw mieszanych do narodowości ojca). W grę wchodzili wszyscy bez wyjątku uprawnieni, w tym osoby pełniące zasadniczą służbę wojskową czy odbywający karę więzienia. Praktyka pokazała, że estońskie MSW lekką ręką wydawało zaświadczenia o niemieckiej przynależności narodowej. $\mathrm{Z}$ tej racji spora grupa Szwedów, Rosjan i Łotyszy wzięła udział w przesiedleniu, o ile nie było sprzeciwu ze strony niemieckiej ${ }^{37}$. Ostateczna decyzja uprawnionych o wyjeździe do Niemiec zależała od nich samych. Jeśli wyrażali taką chęć, zrzekali się obywatelstwa estońskiego, zaś III Rzesza zgadzała się na nadanie im obywatelstwa niemieckiego.

Istotne miejsce $\mathrm{w}$ protokole zajmowały naturalnie regulacje finansowe i gospodarcze. Przesiedleńcy bez żadnych opłat celnych mogli zabrać z sobą lub wywieźć w ciągu trzech miesięcy po opuszczeniu Estonii artykuły gospodarstwa domowego, meble, biżuterię o maksymalnej wartości 500 koron, a także symboliczną gotówkę

34 Ibidem.

35 P. Łossowski, op. cit., s. 81-82.

${ }^{36}$ PAAA, Gesandtschaft Reval 96, 81/1, Umsiedlung der deutschen Volksgruppe Estlands nach Deutschland, Reval, den 16. Oktober 1939, s. 271.

37 O. Angelus, Die Umsiedlung der Estlanddeutschen 1939/1940 in estnischer Sicht, „Baltische Hefte” 15, 1969, s. 111-112. 
(50 estońskich koron czyli 60 marek). Poza tym obowiązywały liczne ograniczenia. Przede wszystkim bez zgody odpowiednich ministerstw nie można było zabierać z sobą przedmiotów o artystycznej i kulturalnej wartości, archiwaliów, samochodów, wyposażenia gabinetów lekarskich. Pozostawiona gotówka miała być przelana na specjalne konto utworzone przez niemieckie poselstwo, a papiery wartościowe $\mathrm{i}$ listy zastawne powierzone $\mathrm{w}$ depozyt tegoż poselstwa.

Pozostawiony majątek ruchomy i, przede wszystkim, nieruchomy miał być przejęty przez Niemiecką Administrację Powierniczą (Deutsche Treuhandverwaltung), utworzoną przy konsulacie Rzeszy jako placówka likwidacyjna. Została ona zobowiązana do ustalenia publicznych i prywatnych długów przesiedleńców. Rząd estoński otrzymał prawo mianowania pełnomocnika, który był uprawniony do wglądu we wszystkie jej księgi. Działalność tej instytucji podlegała estońskiemu prawu materialnemu i procesowemu. Ponadto Niemiecka Administracja Powiernicza została zobowiązana, aby przy administrowaniu i likwidacji majątku przesiedleńców uwzględniać gospodarcze interesy Estonii ${ }^{38}$.

Do powstania tego urzędu do spraw majątku przesiedleńców doszło, w dużej mierze, dzięki uporowi niemiecko-bałtyckich doradców. W żadnym z późniejszych traktatów przesiedleńczych nie udało się III Rzeszy powołać do życia podobnej państwowej instytucji do spraw uregulowania kwestii majątkowych. Berlin musiał zadowalać się towarzystwami akcyjnymi lub spółkami z ograniczoną odpowiedzialnością ${ }^{39}$. Kwestia transferu pozostawionego majątku miała być rozstrzygnięta w późniejszym porozumieniu clearingowym.

$\mathrm{Na}$ Łotwie pertraktacje ciągnęły się o wiele dłużej. Najpierw strona łotewska oznajmiła, że wyrazi zgodę na wyjazd ludności niemieckiej, gdy Niemcy udowodnią, że nie zamierzają zrujnować gospodarki łotewskiej i zgodzą się na rozsądne formy rekompensaty ${ }^{40}$. Widać było od samego początku, że Łotysze zamierzają twardo bronić swoich interesów. Dochodziło zresztą czasami do sytuacji kuriozalnych, jak np. dłuższa dyskusja na temat tego, czy Niemcy mają prawo czegoś żądać, czy tylko mogą, jak to chciała strona łotewska, prosić ${ }^{41}$. Najwięcej trudności sprawiała kwestia wywozu majątku ruchomego. Pierwotnie strona łotewska sprzeciwiała się kategorycznie zezwoleniu na wyjazd tych Niemców, którzy nie zapłacili podatków lub nie podpiszą zobowiązania, że nie będą wysuwać żadnych roszczeń finansowych względem państwa łotewskiego ${ }^{42}$. Z tego powodu rozmowy utknęły w martwym punkcie i były nawet czasowo przerwane. Pierwotnie strona niemiecka chciała uzyskać podobne regulacje jak w Estonii, co natrafiło na zdecydowany sprzeciw Łotyszy. Ci ostatni stali twardo na stanowisku, że

38 D. Loeber, op. cit., dok. 250, s. 471-475.

39 Ibidem, dok. 321, s. 672-673.

40 P. Łossowski, op. cit., s. 82.

41 PAAA, Gesandtschaft Riga 91, 84/4, An der sehr geehrter Deutschen Gesandte Herrn von Kotze, Riga am 23. Oktober 1939, s. 295.

42 PAAA, Büro des Staatssekretärs, R 29895, Aufzeichnung, Berlin, den 9. Oktober 1939, s. 253. 
wartość pozostawionego majątku powinna być wyceniona przez państwo łotewskie. Wyraźnie to też podkreślił, w ostrych słowach, na spotkaniu z przywódcami mniejszości niemieckiej 17 października 1939 r. prezydent Łotwy Ulmanis ${ }^{43}$. W zaistniałej sytuacji sami Niemcy bałtyccy zaczęli nalegać na posła niemieckiego, aby niezależnie od tej jakże spornej kwestii, jak najszybciej doprowadził do podpisania układu, by możliwie jak najprędzej rozpocząć akcję przesiedleń$\mathrm{czą}^{44}$. W związku z tym Weizsäcker wezwał łotewskiego posła w Berlinie, Edgarsa Krievinsa, aby porozmawiać na temat zaistniałych trudności. Chodziło o trzy punkty sporne: 1) umożliwienie jak najszybszego wyjazdu Niemców z Łotwy, w szczególności tych, którzy nie mają żadnego znaczenia dla życia gospodarczego; 2) zobowiązanie rządu niemieckiego do nienaciskania na zbyt szybką likwidację własności Niemców bałtyckich, aby nie wpędzić łotewskiej gospodarki w trudności; 3) powołanie jakiejś placówki, która zajęłaby się zabezpieczeniem i zarządzaniem pozostawionej własności oraz spłaceniem zobowiązań repatriantów wobec państwa łotewskiego i osób fizycznych ${ }^{45}$. Mimo pata rozmowy zostały wkrótce potem podjęte, tym razem w bardzo małym kręgu. Uczestniczyli w nich tylko: ze strony niemieckiej - przedstawiciel Ministerstwa Finansów w Rzeszy Litter, a łotewskiej - minister spraw zagranicznych Munters, któremu czasami towarzyszył minister sprawiedliwości Apsītis ${ }^{46}$. Umożliwiło to w końcu osiągnięcie porozumienia 30 października $1939 \mathrm{r}$.

W przeciwieństwie do Estonii, przybrało ono formę traktatu państwowego. Nie groziło to wszakże dalszą zwłoką w wejściu w życie z powodu debaty ratyfikacyjnej $\mathrm{w}$ parlamencie, $\mathrm{z}$ tej prostej przyczyny, że na Łotwie, po przewrocie w 1934 r., parlamentu po prostu nie było. Wszystkie uprawnienia Saeimy przeszły na rząd. Traktat z dołączonym do niego protokołem dodatkowym zawierał o wiele więcej szczegółowych regulacji niż omówiony wyżej niemiecko-estoński protokół z 15 października.

Układ umożliwiał podobnym grupom osób wzięcie udziału w akcji przesiedleńczej, z tym że, ponieważ nie było tu niemieckiego katastru, podstawę stanowić miała karta członkowska Niemieckiej Wspólnoty Narodowej na Łotwie (Deutsche Volksgemeinschaft in Lettland). Ze strony łotewskiej miał zostać powołany specjalny urząd, który zająłby się uregulowaniem wszelkich spraw majątkowych wynikłych $\mathrm{z}$ akcji przesiedleńczej. Z kolei strona niemiecka miała w tym

${ }^{43}$ J. von Hehn, Zum deutsch-lettischen Verhältnis im Jahre 1939. Drei Bericht der Präsidenten der Deutschen Volksgemeinschaft in Lettland: A. Intelmann über seine Audienzen beim lettländischen Staats- und Ministerpräsidenten K. Ulmanis, „Zeitschrift für Ostforschung” 23, 1974, s. $672-673$.

${ }^{44}$ J.G. Herder-Institut, Archiv, Marburg HIB 216, A. Intelmann, Aufzeichnung aus dem letzten Arbeitsjahr der deutschbaltischen Volksgruppe in Lettland u. Nachklänge im Warthegau, t. 3, s. 106-109.

45 PAAA, Gesandtschaft Riga 91, 84/4, Abschrift Kult. Bericht spez., s. 298-299.

${ }^{46}$ Ibidem, 84/4, Notiz, s. 291. 
celu stworzyć Przesiedleńcze Powiernicze Towarzystwo Akcyjne (Umsiedlungs-Treuhand-Aktien-Gesellschaft - UTAG), bazujące na łotewskim prawie o towarzystwach akcyjnych. Jego kierownictwo miało spoczywać wyłącznie w rękach Reichsdeutschów. Podobnie jak w Estonii, zabroniono wywozu wielu elementów majątku ruchomego oraz gotówki powyżej 50 łatów (około 40 Reichsmark). Wraz $\mathrm{z}$ wyjazdem przesiedleńców pieczę nad pozostawionymi przez nich nieruchomościami przejmował rząd łotewski, natomiast zarządzane miały być przez wyżej wspomniany UTAG, z tym że po 31 stycznia 1940 r. gospodarstwa rolne miały być bezpośrednio przekazane w ręce łotewskie za 200 łatów za hektar. Natomiast nieruchomości w miastach miały pozostać pod kontrolą UTAG do 31 grudnia $1941 \mathrm{r}$. Podobnie jak w Estonii przewidziano stworzenie specjalnego konta przy UTAG, na które miały być przelane oszczędności bankowe przesiedleńców. Artykuł XVIII przewidywał, iż transfer wartości majątku pozostawionego przez przesiedleńców oprze się głównie na dodatkowym eksporcie Łotwy do Niemiec ${ }^{47}$.

Praktycznie prawie natychmiast po podpisaniu rzeczonych układów rozpoczęła się akcja przesiedleńcza, w wyniku której Estonię do połowy listopada 1939 r., kiedy uznano akcję za zakończoną, opuściło 13700 osób, a Łotwę, do połowy grudnia, 52583 osoby. Mimo często wcześniej wrogich stosunków między Niemcami bałtyckimi a Estończykami, a zwłaszcza Łotyszami, repatriacja przebiegała spokojnie i nie odnotowano wrogich aktów ze strony tych ostatnich. Nawet raporty przedstawicieli Rzeszy podkreślały, że większość Łotyszy była obojętna wobec faktu wyjazdu Niemców, zaś pewne grupy na wsi były nawet rozczarowane i żałowały, że ich niemieccy sąsiedzi opuszczają Łotwę. Jedyną w pełni usatysfakcjonowaną grupą społeczną była inteligencja. Zadowolenia z faktu, że Niemcy na zawsze opuszczają Łotwę, nie kryły też władze tego kraju. Na wspólnym posiedzeniu Izby Gospodarczej i Kulturalnej Ulmanis powiedział, przy nieustającym aplauzie: „Uz nieatgriešanos" (nie do zobaczenia) ${ }^{48}$. Wkrótce potem władze łotewskie przystąpiły do wymazywania wszelkich śladów niemczyzny w ich kraju. Na początku 1940 r. poleciły zmienić wszystkie nazwiska pochodzenia niemieckiego na łotewsko brzmiące. W gorliwości posunęly się do tego, iż usuwały nawet napisy niemieckie z grobów czy pod obrazami w kościołach ${ }^{49}$. Wszystko to sprawiało wrażenie, że oficjalna Łotwa chciała jak najszybciej zapomnieć o byłych już teraz sąsiadach, sprawić, aby ci „źli” sąsiedzi zostali w ogóle wymazani z historii.

47 D. Loeber, op. cit., dok. 270, s. 515-524.

48 A. Topij, Mniejszość niemiecka na Łotwie i w Estonii 1918-1939/41, Bydgoszcz 1998, s. 416-417.

${ }^{49}$ Ibidem, s. 418. 


\section{German-Estonian and German-Latvian Treaties on the Resettlement of Baltic Germans' (1939)}

\section{Abstract}

On 6 October 1939, the Reichskanzler Adolf Hitler gave a famous speech in the Reichstag. He proposed, among others, the resettlement of German minorities from a number of European countries to avoid possible conflicts with Germany. In fact, the proposal concerned mainly the Germans living in the sphere of influence of the Soviet Union, including two of the Baltic States: Latvia and Estonia.

Otherwise, the Baltic Germans - as they were called - had expressed their desire to leave for the Third Reich in the first weeks of World War II. They - quite rightly - supposed that shortly the Baltic States would be incorporated into the Soviet Russia. This was corroborated by Soviet demands towards Estonia at the end of September. As a result, the Estonian Germans began to leave their houses in panic, followed by their compatriots in neighbouring Latvia. In this situation, the Auswärtiges Amt (Foreign Office) itself came into contact with the Kriegsmarine (German Navy) in order to make it possible for the Baltic Germans to leave for Germany in the event of a possible occupation of Latvia and Estonia by Soviet military forces. Naturally, top officials had already known about the intention of Hitler, contrary to German diplomatic posts in Riga and Tallinn, confused on the matter and not knowing what to do during an impending crisis. After Hitler's Reichstag speech, the German government made an official proposal to Latvia and Estonia to resettle their citizens of German origin. They wanted to conduct the resettlement as quickly as possible, almost instantly, even at the cost of financial disadvantage to the local Germans. Nonetheless, neither Latvian nor Estonian authorities agreed to such a swift action. They were of the opinion that the proposed resettlement should be based on a legal basis.

As a result, the German authorities were obliged to enter negotiations. German-Estonian talks proceeded in a friendly mood and a final agreement was reached in five days. On 15 October, a German-Estonian protocol on the matter was signed. It was favourable for the Germans, since it took into account the issue of properties of churches, organizations, schools, etc. left by repatriates. It was a different story in Latvia, where a traditionally anti-German regime of Kārlis Ulmanis made demands difficult for Germans to accept. For a time, the talks were deadlocked, but after the intervention of the State Secretary at the Auswärtiges Amt Ernst von Weizsäcker they were shortly reopened. As a result, the Latvian-German treaty was signed two weeks after the Estonian protocol. It was less favourable for the Germans, especially in the area of their property. The resettlement action itself was carried out very swiftly and efficiently. By mid-December of 1939 13,700 Baltic Germans left Estonia and 52,383 left Latvia. It was an overwhelming majority of the German population in the two Baltic States. Those who decided to stay on in their old homeland where not regarded as members of a national minority. Especially the Latvian authorities were eager to erase any German traces from the public life.

Translated by Grażyna Waluga

\section{Германо-эстонское и германо-латвийское соглашения о переселении балтийских немцев (1939 г.)}

\section{Абстракт}

6 октября 1939 г. рейхсканцлер Адольф Гитлер произнес в Рейхстаге знаменитую речь. Он предложил, среди прочего, переселение немецкого меньшинства из ряда европейских 
стран во избежание любого будущего конфликта между Германией и данным государством, населенным фольксдойче (этническими немцами). На самом деле, предложение касалось главным образом немцев, живущих в сфере влияния Советского Союза, включая два из прибалтийских государств: Латвию и Эстонию.

На самом деле балтийские немцы изъявили желание уехать в Третий рейх даже раньше - в первых неделях Второй мировой войны. Они полагали, и оказались правы, что государства Прибалтики вскоре будут присоединены к советской России. Их предчувствия подтвердились советскими требованиями к Эстонии, предъявленными в конце сентября. В результате, эстонские немцы начали в панике покидать свои дома, а вслед за ними последовали их соотечественники из соседней Латвии. В такой ситуации немецкое Министерство иностранных дел связалось с Кригсмарине, чтобы в случае возможной оккупации Латвии и Эстонии советскими войсками, сделать возможной репатриацию балтийских немцев в Германию. Естественно, чиновничья верхушка знала о намерениях Гитлера, в отличие от германских дипмиссий в Риге и Таллинне, которые были сбиты с толку этим вопросом и не знали, что делать в случае надвигающегося кризиса.

После рейхстаговской речи Гитлера немецкое правительство официально предложило Латвии и Эстонии переселение немцев. Оно хотело сделать это как можно скорее, почти сразу, даже с финансовым ущербом для собственного населения. Тем не менее, ни латвийские, ни эстонские власти не согласились на такие быстрые действия. Они считали, что предлагаемое переселение должно основываться на законной основе.

В итоге немецкие власти были вынуждены вступить в переговоры. Германо-эстонские проходили в дружественной атмосфере и быстро, уже пять дней спустя, результат был достигнут. 15 октября был подписан германо-эстонский протокол по данному вопросу. Он был выгодным для немецкой стороны, так как учитывал вопрос имущества церквей, организаций и школ, оставленных репатриантами.

Совсем по-другому было в Латвии, где традиционно антинемецкий режим Карлиса Улманиса выдвинул требования, на которых немцам трудно было согласиться. На какое-то время переговоры были даже сорваны, но после вмешательства Эрнста фон Вайцзеккера, статс-секретаря в Министерстве иностранных дел, на самом деле второго должностного лица в тогдашней немецкой внешней политике, их вскоре возобновили. В результате латвийско-германский договор тоже был заключен, хотя на две недели позже эстонского протокола. Он был менее выгодным для немцев, особенно в вопросе их имущества.

Сама переселенческая акция была осуществлена очень быстро и эффективно. К середине декабря 1939 г. 13700 балтийских немцев покинуло Эстонию и 52383 - Латвию. Они составляли подавляющее большинство немецкого населения этих двух прибалтийских государств. С теми, кто решился остаться на своей старой родине, не обращались как с членами национального меньшинства. Латвийские власти особенно жаждали стереть любые немецкие следы из публичной сферы жизни.

Перевод Агнешка Поспишиль

\section{Bibliografia}

\section{Źródła:}

Akten zur deutschen auswärtigen Politik 1918-1945, Seria D, t. 7, Baden-Baden 1953.

Der großdeutsche Freiheitskampf. Reden Adolf Hitlers, t. 1, München 1943.

Dokumente der Deutschen Politik, t. 7, cz. 1, hrsg. P. von Meier-Benneckenstein, Berlin 1940. 
Wybór tekstów źródłowych z historii państwa i prawa. Okres okupacji hitlerowskiej na ziemiach polskich, wyb. i oprac. A. Konieczny, Wrocław 1980.

Loeber D., Diktierte Option. Die Umsiedlung der Deutschbalten aus Estland und Lettland 19391941. Dokumentation, Neumünster 1972.

\section{Opracowania:}

Angelus O., Die Umsiedlung der Estlanddeutschen 1939/1940 in estnischer Sicht, „Baltische Hefte" 15, 1969, s. 104-143.

Bernsdorff H., Gesundheitsdienst und Fürsorge während der deutsch-baltischer Umsiedlung, „Baltische Hefte” 16, 1970, s. 210-259.

Hehn J. von, Die Umsiedlung der baltischen Deutschen. Das letzte Kapitel baltischdeutscher Geschichte, Marburg 1982.

Hehn J. von, Zum deutsch-lettischen Verhältnis im Jahre 1939. Drei Berichtder Präsidenten der Deutschen Volksgemeinschaft in Lettland: A. Intelmann über seine Audienzen beim lettländischen Staats- und Ministerpräsidenten K. Ulmanis, „Zeitschrift für Ostforschung” 23, 1974, s. 661-675.

Korzeń J., Dramat narodów battyckich, Warszawa 1987.

Kroeger E., Der Auszug aus der alten Heimat. Die Umsiedlung der Baltendeutschen, Tübingen 1967.

Łossowski P., Przesiedlenie Niemców z państw bałtyckich $w$ latach 1939-1941, „Dzieje Najnowsze" 36, 2004, nr 1, s. 75-88.

Plakans A., The Latvians. A Short History, Stanford 1995.

Raun T.U., Estonia and the Estonians, Stanford 2001.

Topij A., Mniejszość niemiecka na Łotwie i w Estonii 1918-1939/1941, Bydgoszcz 1998.

Andrzej Topij, prof. nadzw., zatrudniony w Instytucie Historii i Stosunków Międzynarodowych Uniwersytetu Kazimierza Wielkiego w Bydgoszczy; zainteresowania badawcze: historia krajów bałtyckich oraz Rosji w XIX i XX w.; obecnie pracuje nad tematem o polityce III Rzeszy w krajach bałtyckich w latach 1941-1944/45 (berchtesgaden8@gmail.com).

Andrzej Topij, associate professor at the Institute of History and International Relations of Kazimierz Wielki University in Bydgoszcz; his research interests include: history of the Baltic States and Russia in the $19^{\text {th }}$ and $20^{\text {th }}$ century; currently he works on the policy of the Third Reich in the Baltic States in 1941-1944/45 (berchtesgaden8@gmail.com). 